\title{
EVALUATION OF OMEGA-3 FATTY ACIDS CONTENT AND ANTIOXIDANT ACTIVITY IN WHEAT (Triticum aestivum L.) LEAVES
}

\author{
Avaliação do teor de ácidos graxos ômega-3 e atividade antioxidante \\ em folhas de trigo (Triticum aestivum L.) \\ Ana Carolina de Aguiar', Marcela Boroski², Elton Gutendorfer Bonafé2, \\ Vanessa Vivian de Almeida ${ }^{3}$, Nilson Evelázio de Souza ${ }^{2}$, Jesuí Vergílio Visentainer ${ }^{4}$
}

\begin{abstract}
The objective of this study was to quantify alpha-linolenic acid (LNA, 18:3n-3) of dried wheat leaves, harvested at different development stages (20,40 and 80 days), to determine the antioxidant potential and the total phenolic compounds of leaves harvested at 80 days, as well as to perform mineral analysis ( $\mathrm{Na}, \mathrm{K}, \mathrm{Fe}, \mathrm{Ca}, \mathrm{Mg}, \mathrm{P}, \mathrm{Zn}, \mathrm{Cu}$ and $\mathrm{Mn}$ ). It was observed a predominance of polyunsaturated fatty acids (PUFA) compared to saturated fatty acids (SFA) in the lipid fraction of leaves. Leaves collected in all periods presented ratios of PUFA/SFA, omega- 6 and omega- 3 fatty acids (n-6/n-3) considered suitable for food. The highest content

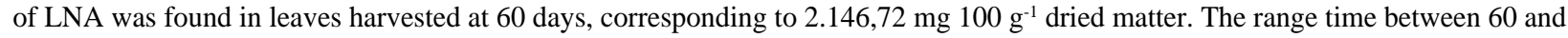
80 days showed a decline of nearly $30 \%$ in the concentration of LNA. The acetate fraction was the most effective over DPPH radical assay, showing $\mathrm{IC}_{50}$ value of $154 \mu \mathrm{g} \mathrm{mL}^{-1}$, and the phenolic compounds content was $615.4 \pm 36.4 \mathrm{mg} \mathrm{EAG} \mathrm{L}^{-1}$, both analyses carried out in leaves harvested at 80 days. In this development stage, wheat leaves showed significant levels of the minerals $\mathrm{P}, \mathrm{Zn}, \mathrm{Cu}$ and $\mathrm{Mn}$. These results reinforce the potential of using wheat leaves in foods, according to its antioxidant content and significant levels of LNA.
\end{abstract}

Index terms: Alpha-linolenic acid, phenolic compounds, antioxidant activity.

\section{RESUMO}

Conduziu-se este estudo, com o objetivo de quantificar o ácido alfa-linolênico (LNA, 18:3n-3) em folhas de trigo secas e colhidas em diferentes estádios de desenvolvimento (20,40 e 80 dias), determinar o potencial antioxidante e o conteúdo de fenólicos totais em folhas colhidas aos 80 dias, assim como realizar a analise de minerais ( $\mathrm{Na}, \mathrm{K}, \mathrm{Fe}, \mathrm{Ca}, \mathrm{Mg}, \mathrm{P}, \mathrm{Zn}, \mathrm{Cu}$ e $\mathrm{Mn}$ ). Foi verificada uma predominância de ácidos graxos poli-insaturados (AGPI) comparado com os ácidos graxos saturados (AGS) na fração lipídica das folhas. As folhas colhidas em todos os períodos apresentaram razões de AGPI/AGS e de ácidos graxos ômega-6 e ômega-3 (n-6/n-3), dentro dos valores considerados adequados para a alimentação. O maior teor de LNA foi encontrado nas folhas colhidas aos 60 dias, correspondendo a 2.146,72 mg $100 \mathrm{~g}^{-1}$ de matéria seca. Entre 60 e 80 dias, observou-se uma queda de cerca de $30 \%$ na concentração de LNA. A fração acetato foi eficiente na inibição do radical DPPH, apresentando valor de $\mathrm{IC}_{50}$ de $154 \mu \mathrm{g} \mathrm{mL} \mathrm{m}^{-1}$, e o teor de compostos fenólicos foi de $615,4 \pm 36,4 \mathrm{mg}_{\mathrm{EAG} \mathrm{L}}{ }^{-1}$, ambas as análises para as folhas colhidas aos 80 dias. Nesse estádio de crescimento, as folhas apresentaram consideráveis teores dos minerais $\mathrm{P}, \mathrm{Zn}, \mathrm{Cu}$ e Mn. Tais resultados reforçam a importância do uso de folhas de trigo para alimentação humana, em função de seu potencial antioxidante e consideráveis teores de LNA.

Termos para indexação: Ácido alfa-linolênico, fenólicos totais, atividade antioxidante.

(Received in august 19, 2010 and approved in february 4, 2011)

\section{INTRODUCTION}

In recent decades, many studies have been performed regarding the beneficial effects of wheatgrass intake. Its consumption has been associated with the fortification of the immune and cardiovascular systems, in addition to detoxifying action in the human body (MARWAHA et al., 2004; TRIANTAFILLIDIS, 2008). Wheatgrass is considered wheat leaves harvested at the first eight days of growth. The wheatgrass has showed antioxidant activity (MOTOMURA et al., 2008), and phenolic content of $1000 \mathrm{mg}$ chlorogenic acid equivalents $100 \mathrm{~g}^{-1}$ dried (CEVALLOS-CASALS; CISNEROSZEVALLOS, 2010). Wheatgrass presented also lipid composition rich in linolenic fatty acid. This fatty acid are produced by $\omega-3$ fatty acid desaturases located in the endoplasmic reticulum and plastid membranes (HORIGUCHI et al., 1996a) and increases with maturation of leaf cells (HORIGUCHI et al., 1996b). Besides these great

\footnotetext{
IUniversidade Federal de Santa Catarina/UFSC - Departamento de Engenharia de Alimentos - Florianópolis, SC 2Universidade Estadual de Maringá/UEM - Departamento de Química/DQI - Maringá, PR

3Universidade Tecnológica Federal do Paraná/UTFPR - Departamento de Química - Apucarana, PR

${ }^{4}$ Universidade Estadual de Maringá/UEM - Departamento de Química/DQI - Avenida Colombo - 5790 - Jardim Universitário - 87020-900 - Maringá, PR jvvisentainer@uem.br
} 
nutritional proprieties, wheatgrass is considered an effective source of minerals ( $\mathrm{K}, \mathrm{Mn}, \mathrm{Zn}, \mathrm{Fe}$ and $\mathrm{Na}$ ) (KULKARNI et al., 2007).

However, despite the extensive literature on chemical and biological effects of wheatgrass intake, few studies are found for wheat leaves harvested at different development.

In general, green leaves have the alpha-linolenic acid (LNA, 18:3 n-3) in their lipid composition, which is an important component of the lipid membrane of chloroplasts (SIMOPOULOS, 2002). Other nutritionally important compounds that are present in leaf tissue are antioxidants such as carotenoids, vitamins, phenols and flavonoids (WANG; LIN, 2000).

The LNA is a polyunsaturated fatty acid of the $n-3$ series (PUFA n-3), precursor of long chain fatty acids in this series, such as docosahexaenoic acid (DHA, 22:6n-3) and eicosapentaenoic acid (EPA, 20:5n-3), considered essential to maintaining a healthy body (Martin et al., 2006). Several studies have showed that they are involved in metabolic processes, cardiovascular activities (PSOTA et al., 2006; SCHACKY; HARRIS, 2007), prevention of chronic neurodegenerative diseases such as Alzheimer's disease (MAZZA et al., 2007), among other effects reported.

A countless variety of foods derived from plants is a source of compounds that have antioxidant activity (MOURE et al., 2001), including herbs (ZHEN; WANG, 2001), mushroom (Agaricus blazei) (SILVA et al., 2009) and some vegetables and fruts (PIENIZ et al., 2009). Antioxidants can be defined as species that when present in low concentrations compared to the oxidizable substrate prevent or retard the oxidation of lipids and other molecules (ZHEN; WANG, 2001). The compounds responsible for this trait, such as alpha-tocopherol, carotenoids, flavonoids and some enzymes, offer protection for plant against stress caused by reactive oxygen species (MISHRA et al., 1993).

Many studies have investigated the importance of consuming foods containing substances with antioxidant properties in its composition, preventing chronic diseases such as cardiovascular diseases, cancer and degenerative brain disorders associated with aging (CHU et al., 2000; LIYANA-PATHIRANA; SHAHIDI, 2006).

Thus, the purpose of this study was to quantify the LNA of wheat leaves harvested at different development stages (20, 40 and 80 days), and to estimate the antioxidant potential against DPPH radical assay, the total phenolic content, and minerals $(\mathrm{Na}, \mathrm{K}, \mathrm{Fe}, \mathrm{Ca}, \mathrm{Mg}, \mathrm{P}$, $\mathrm{Zn}, \mathrm{Cu}$ and $\mathrm{Mn}$ ) of leaves harvested at 80 days.

\section{MATERIAL AND METHODS}

The experiment was conducted in the countryside of Maringá - PR $\left(23^{\circ} 25^{\prime}\right.$ south and $51^{\circ} 57^{\prime}$ west $)$ from March to May 2007. The average altitude is $596 \mathrm{~m}$ and the climate is mesothermal humid, Cfa type (Köppen).

The plot consisted of six rows of $4 \mathrm{~m}$ long, spaced $0.50 \mathrm{~m}$. Plants were harvested manually at 20,40 and 80 days, washed in water, dried in an oven with circulating air for 48 hours at $40^{\circ} \mathrm{C}$, milled in a grinder of knives, stored in polyethylene bags at $-18^{\circ} \mathrm{C}$ and then subjected to analysis.

\section{Extraction of total lipids}

The total lipids were extracted according to the methodology of Bligh e Dyer (1959) with modification in the solvents volumes. Samples (1.00 g) was added into a misture of $30 \mathrm{~mL}$ chloroform-methanol $(1: 2 \mathrm{v} / \mathrm{v})$ and shaken vigorously for 5 minutes, following by addition of $10 \mathrm{~mL}$ of chloroform, kept under stirring for 2 minutes, and $18 \mathrm{~mL}$ of distilled water, agitated for 5 minutes. The mixture was filtered under vacuum on Büchner funnel. The organic solvent phase containing chloroform and lipids was drained into flask and the solvent removed in rotary evaporator under vacuum at $40^{\circ} \mathrm{C}$. Lipid content was determined gravimetrically. All chemical tests were performed in triplicate.

\section{Transesterification and analysis of methyl esters of fatty acids}

The fatty acid methyl esters (FAME) were prepared by the method of Hartman e Lago (1973), modified by Maia e Rodrigues-Amaya (1993). The FAME were analyzed in a Shimadzu 14-A (Kyoto, Japan) gas chromatography equipped with a flame ionization detector (FID) and a fused silica capillary column CP-Select CB-FAME (100 m x $0.25 \mathrm{~mm}$ id., $0.25 \mu \mathrm{m}$ film thickness, Varian, EUA). The operational parameters were as follows: detector temperature, $230^{\circ} \mathrm{C}$; injection temperature, $220^{\circ} \mathrm{C}$; column temperature, from 150 to $185^{\circ} \mathrm{C}$ at $2^{\circ} \mathrm{C} \mathrm{min}{ }^{-1}$ and to $225^{\circ} \mathrm{C}$ at $10^{\circ} \mathrm{C} \mathrm{min}^{-1}$, final holding time of $20 \mathrm{~min}$; carrier gas, hydrogen at $1.2 \mathrm{~mL}$ $\mathrm{min}^{-1}$; make-up, nitrogen gas at $30 \mathrm{~mL} \mathrm{~min}^{-1}$; split injection at 1:100 ratio. Sample $(2.0 \mu \mathrm{L})$ was injected into the gas chromatograph. Peak areas were determined in CG-300 Computing integrator (CG Instruments, Brazil) and FAME were identified by comparison with known retention times of standards from Sigma (USA).

\section{Quantification of alpha-linolenic acid}

Quantification (in mg fatty acid $\mathrm{g}^{-1}$ of total lipids) was made against tricosanoic acid methyl ester as an internal standard (23:0), as described by Joseph e Ackman (1992). Theoretical FID (flame ionization detector) correction 
factor (VISENTAINER; FRANCO, 2006) values were used to obtain concentration values. Fatty acid contents were calculated in $\mathrm{mg} \mathrm{g}^{1}$ of total lipids by using equation 1 .

$$
F A=\frac{A_{x} W_{I S} C F_{X}}{A_{I S} W_{X} C F_{A E}}
$$

where FA is mg of fatty acids per $g$ of total lipids, $A_{X}$ is the peak area (fatty acids), $A_{I S}$ is the peak area of internal standard (IS) methyl ester of tricosanoic acid (23:0), $\mathrm{W}_{\text {IS }}$ is the IS weight ( $\mathrm{mg}$ ) added to the sample (in $\mathrm{mg}$ ), $\mathrm{W}_{\mathrm{X}}$ is the sample weight (in $\mathrm{mg}$ ), $\mathrm{CF}_{\mathrm{X}}$ is the theoretical correction factor, and $\mathrm{CF}_{\mathrm{AE}}$ is the conversion factor necessary to express results as $\mathrm{mg}$ of fatty acids rather than as methyl esters.

The results were converted from $\mathrm{mg} \mathrm{g}^{-1}$ of total lipids to $\mathrm{mg}$ fatty acid $100 \mathrm{~g}^{-1}$ dried leaves.

\section{Mineral content}

The minerals ( $\mathrm{Na}, \mathrm{K}, \mathrm{Fe}, \mathrm{Ca}, \mathrm{Mg}, \mathrm{P}$ and $\mathrm{Zn}$ ) of leaves harvested at 80 days were determined by atomic absorption spectrometry as described in AOAC (CUNNIFF, 1998).

\section{Antioxidant activity}

Methanol extract was prepared by the $48 \mathrm{~h}$ percolation of $70 \mathrm{~mL}$ through $10.0 \mathrm{~g}$ of dried leaves harvested at 80 days. New rates of methanol was added every $24 \mathrm{~h}$. After being filtered, the extracts were concentrated under reduced pressure at $40^{\circ} \mathrm{C}$. A fraction of methanol extract was performed using solvents of increasing polarity: hexane, ethyl acetate, 1-butanol and water. The fractions were collected separately and evaporated under reduced pressure.

The antioxidant capacity of 80-days dried leaves were studied against 1,1-diphenyl-2-picrylhydrazyl (Sigma) according to El-Massary et al. (2002). Different aliquots of extract solutions prepared by addition of $20.0 \mathrm{mg}$ of methanolic extract and $10 \mathrm{~mL}$ methanol were mixed with $2.0 \mathrm{~mL}$ of DPPH methanolic solution. The mixture was thoroughly vortex-mixed and kept in the dark for $30 \mathrm{~min}$. Next, absorbance was measured at $517 \mathrm{~nm}$ against a methanol blank without DPPH using specrophotometer (Cary Win UV 50, Varian). The results were expressed as percent inhibition of the DPPH radical (\% inhibition DPPH'), which was calculated according to the following equation 2 .

$$
\% \text { InhibitionDPPH } H^{\bullet}=\frac{\left(A b s_{D P P H} \cdot-A b s_{\text {sample }}\right)}{A b s_{D P P H}} \times 100
$$

where $\mathrm{Abs}_{\mathrm{DPPH}}$ is the absorbance of the $\mathrm{DPPH}^{\bullet}$ solution without extracts, and $\mathrm{Abs}_{\text {sample }}$ is the absorbance of the sample solution.

The analyses were carried out in triplicate and the extract concentration providing $50 \%$ inhibition $\left(\mathrm{IC}_{50}\right.$ ) was obtained by plotting the concentrations of the extract solutions versus percent inhibition.

Total phenolics were determined according to the Shahidi e Naczk (1995) method with slight modifications. A $0.25-\mathrm{mL}$ aliquot of extract solution $\left(2.50 \mathrm{mg} \mathrm{mL}^{-1}\right.$ in methanol) was mixed with $0.25 \mathrm{~mL}$ of Folin-Ciocalteu reagent previously diluted with water $1: 1 \mathrm{v} / \mathrm{v}, 0.50 \mathrm{~mL}$ of a saturated sodium carbonate solution and $4.0 \mathrm{~mL}$ of water. The mixture was rested at room temperature for $25 \mathrm{~min}$ and then centrifuged at 5000 rpm for $10 \mathrm{~min}$. The supernatant absorbance was measured at $725 \mathrm{~nm}$ using a spectrophotometer (Cary Win UV 50, Varian). The results were expressed as milligrams gallic acid equivalents per $\mathrm{L}\left(\mathrm{mg} \mathrm{GAE} \mathrm{L} \mathrm{L}^{-1}\right)$.

\section{Statistical analysis}

The results were submitted to variance (ANOVA) analysis and Tukey's test (5\% probability) using the software Statistica 5.0 (STATISTICA, 1995).

\section{RESULTS AND DISCUSSION}

The lipid contents were 3.21, 3.29, 3.91 and $2.73 \mathrm{~g}$ $100^{-1} \mathrm{~g}$ of dried matter for 20, 40,60 and 80 days respectively. It was found saturated fatty acids (SFA), monounsaturated fatty acids (MUFA) and polyunsaturated fatty acids (PUFA) in wheat leaves. Among the SFA, were identified myristic (14:0), palmitic (16:0), stearic (18:0), behenic (22:0) and lignoceric (24:0) acids. A predominance of palmitic acid, ranged from 309.92 to $509.95 \mathrm{mg} 100 \mathrm{~g}^{-1}$ of dried leaves, was observed in this category of fatty acids. The MUFA consisted in palmytoleic (16:1 n-7) and oleic acid (18:1 n-9). The PUFA were the largest fatty acid portion found in wheat leaves, and linoleic acid (LA, 18:2n-6) and LNA were detected. The LNA was the most abundant in the lipid fraction extracted from wheat leaves (Table 1), with mass percentage ranging from 63.4 to $75.0 \%$.

The LNA values for wheat leaves harvested at 20, 40 and 60 days did not differ significantly $(\mathrm{P}<0.05)$. There was a significant decrease $(\mathrm{P}<0.05)$ in the LNA concentration in the wheat leaves between 60 and 80 days.

Almeida et al. (2006) reviewed different types of

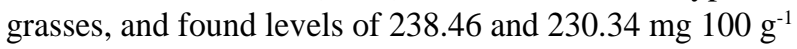
of dried matter of Brachiaria decumbens and Rynchospora speciosa, respectively, both values lower than those found for wheat leaves at different growth times. 
Table 1 - Fatty acids concentration (mg $100 \mathrm{~g}^{-1}$ dried material) in wheat leaves at different growth stages.

\begin{tabular}{ccccc}
\hline & 20 days & 40 days & 60 days & 80 days \\
\hline $14: 0$ & $11.52^{\mathrm{b}} \pm 10.42$ & $17.90^{\mathrm{b}} \pm 3.08$ & $41.08^{\mathrm{a}} \pm 5.78$ & $20.56^{\mathrm{b}} \pm 7.08$ \\
$16: 0$ & $317.42^{\mathrm{ab}} \pm 133.86$ & $309.92^{\mathrm{b}} \pm 38.08$ & $509.95^{\mathrm{a}} \pm 106.11$ & $377.89^{\mathrm{ab}} \pm 121.23$ \\
$16: 1 \mathrm{n}-7$ & $26.78^{\mathrm{ab}} \pm 8.25$ & $31.36^{\mathrm{a}} \pm 3.34$ & $33.45^{\mathrm{a}} \pm 5.06$ & $21.82^{\mathrm{b}} \pm 7.55$ \\
$18: 0$ & $57.66^{\mathrm{a}} \pm 8.96$ & $27.35^{\mathrm{b}} \pm 7.70$ & $61.39^{\mathrm{a}} \pm 7.09$ & $28.68^{\mathrm{b}} \pm 8.54$ \\
$18: 1 \mathrm{n}-9$ & $40.49^{\mathrm{b}} \pm 6.59$ & $51.31^{\mathrm{b}} \pm 13.16$ & $96.11^{\mathrm{a}} \pm 16.92$ & $36.99^{\mathrm{b}} \pm 12.91$ \\
$18: 2 \mathrm{n}-6$ & $226.71^{\mathrm{b}} \pm 25.09$ & $238.98^{\mathrm{b}} \pm 23.61$ & $338.57^{\mathrm{a}} \pm 36.09$ & $285.87^{\mathrm{ab}} \pm 88.33$ \\
$18: 3 \mathrm{n}-3$ & $1,979.63^{\mathrm{ab}} \pm 79.55$ & $2,034.31^{\mathrm{a}} \pm 137.21$ & $2,146.72^{\mathrm{a}} \pm 258.07$ & $1,438.98^{\mathrm{b}} \pm 467.90$ \\
$22: 0$ & $13.98^{\mathrm{a}} \pm 1.71$ & $19.17^{\mathrm{a}} \pm 6.06$ & $17.00^{\mathrm{a}} \pm 6.56$ & $26.56^{\mathrm{a}} \pm 7.52$ \\
$24: 0$ & $3.94^{\mathrm{b}} \pm 0.13$ & $9.31^{\mathrm{bc}} \pm 0.87$ & $17.87^{\mathrm{c}} \pm 2.85$ & $34.15^{\mathrm{a}} \pm 10.25$ \\
\hline
\end{tabular}

Values are mean \pm standard deviation of triplicate analyses. Different letters in the same line indicate significant differences $(\mathrm{P}<0.05)$ by Tukey test.

In wheat leaves, the ratios obtained of polyunsaturated fatty acids and saturated fatty acids (PUFA/SFA) ranged from 3.54 (80 days) to 5.93 (40 days). According to the recommendation of the Department of Health (HER MAJESTY'S STATIONERY OFFICE -HMSO, 1994), this ratio in the diet should be higher than 0.45 in relation to cardiovascular disease.

For the ratio of n- 6 and n-3 fatty acids was found the mean value of 0.15 . In most Western countries, there is a growing concern in decreasing dietary $n-6 / n-3$ ratio to values between 10 and 5:1 (DAVIS; KRIS-ETHERTON, 2003). This condition can be favored by the insertion of wheat leaves in the diet.

Evidence from epidemiological studies suggests that diets rich in $n$ - 3 PUFA may be associated with reduced cancer risk (BARACOS et al., 2004). Although the lipid content in plant tissues is not high, the presence of nutritional fatty acids, such n-3 fatty acids, provides increasing intake of these on the diet (MARTIN et al., 2006). According to both ratios presented below, these leaves can be considered nutraceutical food.

It was established that the recommended daily intake (RDI) of LNA for men and women aged between 19 and 70 years is 1.1 and $1.6 \mathrm{~g}$, respectively (INSTITUTE OF MEDICINE OFTHE NATIONALACADEMIES, 2002). The incorporation of about $20 \mathrm{~g}$ of dried wheat leaves in the diet of individuals in this age group provides around $28 \%$ of the RDI for this fatty acid.

The changes on fatty acid composition during growth are related to alterations in lipid membranes (WANG; LIN, 2006). Temperature and other environmental factors (CHAPMAN et al., 1983), the salinity levels
(TAARIT et al., 2010) and the geomagnetic field (NOVITSKAYA et al., 2006) are factors affecting fatty acid composition of plant growth in Nature.

The antioxidant activity of wheat leaves harvested at 80 days showed satisfactory values, especially for the acetate fraction, which inhibited $50 \%$ of the absorbance of DPPH radical $\left(\mathrm{IC}_{50}\right)$ after the addition of $154 \mu \mathrm{g} \mathrm{mL}^{-1}$ of acetate extract (Table 2). In this analysis, the higher the $\mathrm{IC}_{50}$ value, the less effective is the antioxidant activity. For the aqueous fraction, this value was higher than 500 $\mu \mathrm{L}$, indicating that the compounds that act as antioxidants in wheat leaves might have intermediate polarity, such as ethyl acetate and 1-butanol alcohol. These compounds range from simple phenolic acids to complex aromatic structures (CHUN et al., 2005).

Cavaliere et al. (2005) detected flavons compounds such as apigenin, luteolin, chrysoeriol, tricin, in their glycoside forms, which might be responsible for antioxidant activity in the leaf tissue of wheat.

Polar solvent, such as methanol (CEVALLOSCASALS; CISNEROS-ZEVALLOS, 2010), water and ethanol (Motomura et al., 2008), have commonly been used to optimize the phenolic compound extraction in wheat leaves. The average of phenolic compound in wheat leaves harvested at 80 days was $615.4 \pm 36.4 \mathrm{mg} \mathrm{GAE} \mathrm{L}^{-1}$. CevallosCasals e Cisneros-Zevallos (2010) found a changing in phenolic content over different development stages, and noted an increase of more than $500 \%$ after 7 days of germination. Table 3 shows the concentration of minerals found in the wheat leaves harvested at 80 days.

There are minerals, such as calcium, phosphorus, magnesium and potassium which are considered 
Table 2 - Antioxidant activity of 80-days wheat leaves extract.

\begin{tabular}{cc}
\hline Fraction & $\mathrm{IC}_{50}\left(\mu \mathrm{g} \mathrm{mL} \mathrm{m}^{-1}\right)$ \\
\hline Hexanic & $241.9^{\mathrm{d}} \pm 2.3$ \\
Acetate & $153.7^{\mathrm{e}} \pm 1.0$ \\
Butanolic & $228.7^{\mathrm{c}} \pm 0.9$ \\
Methanolic & $387.0^{\mathrm{b}} \pm 3.8$ \\
Water & $>500^{\mathrm{a}}$ \\
\hline
\end{tabular}

Values are mean \pm standard deviation of triplicate analyses. Different letters in the same column indicate significant differences $(\mathrm{P}<0.05)$ by Tukey test.

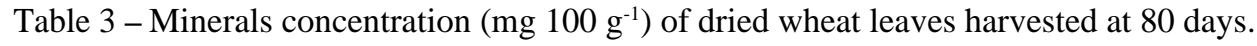

\begin{tabular}{cccc}
\hline Mineral & Concentration & Mineral & Concentration \\
\hline Sodium $(\mathrm{Na})$ & $5.79 \pm 0.14$ & Total phosphorus $(\mathrm{P})$ & $46.25 \pm 1.16$ \\
Potassium $(\mathrm{K})$ & $6.12 \pm 0.26$ & Zinc $(\mathrm{Zn})$ & $9.07 \pm 0.04$ \\
Iron $(\mathrm{Fe})$ & $18.84 \pm 0.61$ & Copper $(\mathrm{Cu})$ & $1.25 \pm 0.02$ \\
Calcium $(\mathrm{Ca})$ & $27.70 \pm 1.25$ & Cobalt $(\mathrm{Co})$ & $\mathrm{Nd}^{1}$ \\
Magnesium $(\mathrm{Mg}):$ & $11.02 \pm 0.11$ & Manganese $(\mathrm{Mn})$ & $10.03 \pm 0.86$ \\
\hline
\end{tabular}

${ }^{1}$ Below the limit of detection $\left(0.0001 \mathrm{mg} \mathrm{kg}^{-1}\right)$.

macronutrients, and are necessary in larger quantities. Moreover, the micronutrients are needed in very small quantities, but with equal importance, such as iron, manganese, copper and zinc (KRAUSE; MAHAN, 1991).

Regarding mineral considered macronutrients, the total phosphorus and calcium showed higher concentrations in leaves and the ingestion of $100 \mathrm{~g}$ of dried leaves would supply about $6.61 \%(\mathrm{P})$ and $2.77 \%(\mathrm{Ca})$ of the RDI for adults, in accordance with current legislation (Brasil, 2005). For minerals considered micronutrients, the intake of 100 grams of wheat leaves would provide $129 \%$ of the RDI for $\mathrm{Zn}, 139 \%$ for $\mathrm{Cu}$ and $426 \%$ for $\mathrm{Mn}$, however it must be considered the bioavailability of these nutrients.

\section{CONCLUSION}

The results indicated that the wheat leaves are abundant in alpha-linolenic acid, especially during the first 60 days of development, and offer considerable antioxidant activity, total phenolics and minerals. This represents an alternative way to feed animals and to increase the LNA levels in the human diet.

\section{REFERENCES}

ALMEIDA, V.V. et al. A influência da composição lipídica de capins sobre a formação de CLA em ruminantes (Conjugated linoleic acid): aspectos gerais. Revista
Nacional da Carne, São Paulo, n.355, p.111-112, set. 2006.

BARACOS, V.E.; MAZURAK, V.C.; MA, D.W.L. n-3 Polyunsaturated fatty acids throughout the cancer trajectory: influence on disease incidence, progression, response to therapy and cancer-associated cachexia. Nutrition Research Reviews, Cambridge, v.17, n.2, p.177-192, 2004.

BLIGH, E.G.; DYER, W.J. A rapid method of total lipid extraction and purification. Canadian Journal of Biochemistry and Physiology, Ontario, v.37, p.911-917, Aug. 1959.

BRASIL. Resolução RDC no 269, de 22 de setembro de 2005. Dispõe sobre o "regulamento técnico sobre a ingestão diária recomendada (idr) de proteína, vitaminas e minerais”. Brasília: ANVISA, 2005.

CAVALIERE, C. et al. Identification and mass spectrometric characterization of glycosylated flavonoids in Triticum durum plants by high-performance liquid chromatography with tandem mass spectrometry. Rapid Communications in Mass Spectrometry, Hoboken, v.19, n.21, p.3143-3158, Oct. 2005. 
CEVALLOS-CASALS, B.A.; CISNEROS-ZEVALLOS, L. Impact of germination on phenolic content and antioxidant activity of 13 edible seed species. Food Chemistry, Barking, v.119, n.4, p.1485-1490, Apr. 2010.

CHAPMAN, D.J.; FELICE, J.; BARBER, J. Influence of winter and summer growth conditions on leaf membrane lipids of Pisum sativum L. Planta, Heidelberg, v.157, p.218-223, 1983.

CHU, Y.H.; CHANG, C.L.; HSU, H.F. Flavonoid content of several vegetables and their antioxidant activity. Journal of the Science of Food and Agriculture, London, v.80, n.5, p.561-566, Apr. 2000.

CHUN, S.S. et al. Phenolic antioxidants from clonal oregano (Origanum vulgare) with antimicrobial activity against Helicobacter pylori. Process Biochemistry, New York, v.40, p.809-816, 2005.

CUNNIFF, P.A. (Ed.). Official methods of analysis of AOAC Internacional. 16.ed. Arlington: AOAC, 1998. CD-ROM.

DAVIS, B.C.; KRIS-ETHERTON, P.M. Achieving optimal essential fatty acid status in vegetarians: current knowledge and practical implications. American Journal of Clinical Nutrition, Bethesda, v.78, p.640S-646S, Sept. 2003.

EL-MASSARY, K.F.E.; EL-GHORAB, A.H.; FAROUK, A. Antioxidant activity and volatile components of Egyptian Artemisia judaica L. Food Chemistry, Barking, v.79, n.3, p.331-336, Mar. 2002.

HARTMAN, L.; LAGO, R.C.A. Rapid preparation of fatty acid methyl esters from lipids. Laboratory Practice, London, v.22, n.8, p.475-476, July 1973.

HER MAJESTY'S STATIONERY OFFICE. Department of Health. Nutritional aspects of cardiovascular disease: report in health and social subjects. London, 1994. $178 \mathrm{p}$.

HORIGUCHI, G. et al. Expression of a gene for plastid $\omega$ 3 fatty acid desaturase and changes in lipid and fatty acid compositions in light- and dark- grown wheat leaves. Physiologia Plantarum, Copenhagen, v.96, n.2, p.275-283, 1996a.
HORIGUCHI, G. et al. Role of $\omega$-3 fatty acid desaturases in the regulation of the level of trienoic fatty acids during leaf cell maturation. Planta, Heidelberg, v.199, n.3, p.439-442, $1996 b$.

\section{INSTITUTE OF MEDICINE OF THE NATIONAL} ACADEMIES. Dietary reference intakes: energy, carbohydrate, fiber, fat, fatty acids, cholesterol, protein and amino acids. Washington: National Academy, 2002.

JOSEPH, J.D.; ACKMAN, R.G. Capillary column gas chromatography method for analysis of encapsulated fish oil and fish oil ethyl esters: collaborative study. Journal of the Association of Official Analytical Chemists, Gaithersburg, v.75, n.3, p.488-506, 1992.

\section{KRAUSE, M.V.; MAHAN, L.K. Alimentos, nutrição e dietoterapia. São Paulo: Roca, 1991. 981p.}

KULKARNI, S.D. et al. Evaluation of bioaccessibility of some essential elements from wheatgrass (Triticum aestivum L.) by in vitro digestion method. Food Chemistry, Barking, v.103, p.681-688, 2007.

LIYANA-PATHIRANA, C.M.; SHAHIDI, F. Antioxidant properties of commercial soft and hard Winter wheats (Triticum aestivum L.) and their milling fractions. Journal of the Science of Food and Agriculture, London, v.86, n.3, p.477-485, Feb. 2006.

MAIA, E.L.; RODRIGUES-AMAYA, D. Avaliação de um método simples e econômico para metilação de ácidos graxos com lipídios de diversas espécies de peixes. Revista do Instituto Adolfo Lutz, São Paulo, v.53, p.27-35, 1993.

MARTIN, C.A. et al. Ácidos graxos poliinsaturados ômega-3 e ômega-6: importância e ocorrência em alimentos. Revista de Nutrição, Campinas, v.19, n.6, p.761-770, nov./dez. 2006.

MARWAHA, R.K. et al. Wheat grass juice reduces transfusion requirement in patients with thalassemia major: a pilot study. Indian Pediatrics, New Delhi, v.41, p.716-720, 2004.

MAZZA, M. et al. Omega-3 fatty acids and antioxidants in neurological and psychiatric diseases: an overview.

Progress in Neuro-Psychopharmacology \& Biological Psychiatry, Quebec, v.31, p.12-26, Jan. 2007. 
MISHRA, N.P.; MISHRA, R.K.; SINGHAL, C.S.

Changes in the activities of anti-oxidant enzymes during exposure of intact wheat leaves to strong visible light at different temperatures in the presence of protein synthesis inhibitors. Plant physiology, Waterbury, v. 102, p. 903-910, 1993.

MOTOMURA, Y.; REYES-DÍAZ, M.; GIL, M.L.M. Effect of selenite on the total polyphenol content and antioxidative activity of aqueous and ethanolic extracts in sprouts of four agronomic species. Journal of Soil Science and Plant Nutrition, Temuco, v.1, n.8, p.55-67, 2008.

MOURE, A. et al. Natural antioxidants from residual sources. Food Chemistry, Barking, v.72, n.2, p.145-171, Feb. 2001.

NOVITSKAYA, G.V.; KOCHESHKOVA, T.K.; NOVITSKII, Y.I. The effects of a weak permanent magnetic field on the lipid composition and content in the onion leaves of various ages. Russian Journal of Plant Physiology, Moscow, v.53, n.5, p.638-648, 2006.

PIENIZ, S. et al. Avaliação in vitro do potencial antioxidante de frutas e hortaliças. Ciência e Agrotecnologia, Lavras, v.33, n.2, p.552-559, mar./abr. 2009.

PSOTA, T.L.; GEBAUER, S.K.; KRIS-ETHERTON, P.

Dietary omega-3 fatty acid intake and cardiovascular risk. The American Journal of Cardiology, Dallas, v.98, n.4, p.3-18, Aug. 2006. Supplement 1.

SCHACKY, C. von; HARRIS, W.S. Cardiovascular benefits of omega-3 fatty acids. Cardiovascular Research, London, v.73, p.310-315, 2007.

SHAHIDI, F.; NACZK, M. Food phenolics: sources, chemistry, effects, applications. Lancaster: Technomic, 1995.331p.
SILVA, A.C. et al. Utilização de extrato de cogumelo como antioxidante natural em óleo vegetal. Ciência e Agrotecnologia, Lavras, v.33, n.4, p.1103-1108, jul./ago. 2009.

SIMOPOULOS, A.P. Omega-3 fatty acids in wild plants, nuts and seeds. Asia Pacific Journal of Clinical

Nutrition, Taiwan, v.11, n.6, p.S163-S173, Sept. 2002.

STATISTICA. Statistica 5.1 software. Tucks, 1995. Software.

TAARIT, M.B. et al. Changes in fatty acid and essential oil composition of sage (Salvia officinalis L.) leaves under $\mathrm{NaCl}$ stress. Food Chemistry, Barking, v.119, p.951-956, 2010.

TRIANTAFILLIDIS, J.K. The use of natural products in the treatment of inflammatory bowel disease.

Annals of Gastroenterology, London, v.21, n.1, p.1416, 2008.

VISENTAINER, J.V.; FRANCO, M.R.B. Ácidos graxos em óleos e gorduras: identificação e quantificação. São Paulo: Varela, 2006. 120p.

WANG, S.Y.; LIN, H.S. Antioxidant activity in fruits and leaves of blackberry, raspberry, and strawberry varies with cultivar and developmental stage. Journal of Agriculture and Food Chemistry, Washington, v.48, n.2, p.140-146, 2000.

WANG, S.Y.; LIN, H.S. Effect of plant growth temperature on membrane lipids in strawberry (Fragaria $\mathrm{x}$ ananassa Duch.). Scientia Horticulturae, Amsterdam, v.108, p.3542, 2006.

ZHEN, W.; WANG, S.Y. Antioxidant activity and phenolic compounds in selected herbs. Journal of Agricultural and Food, Washington, v.49, p.5165-5170, 2001. 